\title{
Elemental Composition of Particulate Matter in the Southeastern Brazilian Ceramic Pole by Synchrotron Radiation X-ray Fluorescence Technique (SR-XRF)
}

\author{
Thiago A. Dourado, ${ }^{a}$ Hendryk Gemeiner, ${ }^{a}$ Ana Carla F. Gomes, ${ }^{b}$ Eduardo Almeida, ${ }^{c}$ \\ Adivania C. da Silva, ${ }^{b}$ Nayara Valadão, ${ }^{b}$ Amauri Antônio Menegário, ${ }^{\circledR} * a$ \\ José Silvio Govone ${ }^{a}$ and Didier Gastmans ${ }^{\odot a}$
}

\author{
${ }^{a}$ Centro de Estudos Ambientais (CEA), Universidade Estadual Paulista (Unesp), \\ 13506-900 Rio Claro-SP, Brazil \\ ${ }^{b}$ Instituto Federal de Educação, Ciência e Tecnologia de Goiás, \\ 74130-012 Goiânia-GO, Brazil
}

${ }^{c}$ Centro de Energia Nuclear na Agricultura, Universidade de São Paulo, 13418-900 Piracicaba-SP, Brazil

\begin{abstract}
In the present study, the elemental content of the particulate matter $\mathrm{PM}_{2.5}$ (particulate matter with diameters lower than $2.5 \mu \mathrm{m}$ ) and $\mathrm{PM}_{10}$ (particulate matter with diameters lower than $10 \mu \mathrm{m}$ ) of the Brazilian city of Rio Claro (SP) were analyzed by synchrotron radiation X-ray fluorescence (SR-XRF) in the Brazilian Synchrotron Light Laboratory (LNLS). A fractional sampling of particulate matter (PM) was carried out in two climatic periods (dry and rainy season). The elemental determination of $\mathrm{PM}_{2.5}$ and $\mathrm{PM}_{10}$ included the following elements: $\mathrm{Si}, \mathrm{S}, \mathrm{Ca}, \mathrm{K}, \mathrm{Ti}, \mathrm{Cr}$, $\mathrm{Mn}, \mathrm{Fe}, \mathrm{Cu}$, and $\mathrm{Zn}$. Elemental correlation studies, cluster analysis, principal component analysis and enrichment factor determination were performed in order to allow the distinction of the main sources of the emission of PM. The mean elementary contents, especially in $\mathrm{PM}_{10}$, were statistically different to each other between the sampling seasons and higher in dry than in rainy season. The cluster analysis indicated two groups as being the main constituting element groups for the composition of PM in Rio Claro. A major group originated by the resuspension of soil composed by the elements $\mathrm{Si}, \mathrm{Fe}, \mathrm{Ca}$ and $\mathrm{K}$, and a second, minor group composed of $\mathrm{S}$, Ti, $\mathrm{Mn}, \mathrm{Cu}, \mathrm{Cr}$, and $\mathrm{Zn}$, presumably influenced by vehicular emissions and the regions adjacent ceramic industries.
\end{abstract}

Keywords: particulate matter, synchrotron radiation, X-ray fluorescence, emission sources, ceramic pole

\section{Introduction}

Atmospheric pollutants are any suspended substances in the air that can be harmful to human health according to its concentration. ${ }^{1}$ The small solid and liquid particles suspended in the atmosphere with a diameter lower than $100 \mu \mathrm{m}$ are defined as particulate matter (PM). ${ }^{2}$ They are characterized by their variation in size, their chemical composition and their processes of formation. ${ }^{3,4}$ They generally not consist of a single chemical species but rather of a set of solid and liquid particles, including dust, smoke and aerosols emitted into the atmosphere through industries, vehicles, civil construction and drag of natural dust. $^{4}$

*e-mail: amauri.antonio-menegario@unesp.br
$\mathrm{PM}_{2.5}$ describes fine inhalable particles with diameters lower than $2.5 \mu \mathrm{m}$. $\mathrm{PM}_{2.5}$ is responsible for a number of cardiorespiratory diseases and other complications due to its capacity to lodge in the bronchioles. ${ }^{5-8} \mathrm{PM}_{10}$ are particles with diameters lower than $10 \mu \mathrm{m}$. These particles are also inhalable but filtered in the nose and nasopharynx. ${ }^{9}$ As to the origin of PM present in the atmosphere, it is known that the natural sources of PM have significant contributions on the coarse particles compared to the anthropogenic sources, which contribute to the formation of fine particles. ${ }^{10}$ The main emitting sources of anthropogenic PM are associated with the burning of automotive fuels, industrial activities and sources of natural origin mainly by the resuspension of soil dust. ${ }^{11}$ Mining activity, especially related to ceramic material, is considered as one of the most harmful industries regarding the production of PM to the atmosphere. ${ }^{12,13}$ 
Considering the amount of pollutants emitted every year, nowadays there are greater concerns about the characterization of PM around the world as a multitude of research studies focus on the composition of PM. Many studies about the characterization of $\mathrm{PM}_{2.5}$ were performed in urban regions of several countries, ${ }^{14-19}$ as well as in urban regions of Brazil, such as the cities of São Paulo and Campinas, among others..$^{20-25}$ The most used techniques for the determination of the elemental composition in PM in mentioned studies are inductively coupled plasma optical emission spectrometry (ICP OES), particle-induced X-ray emission (PIXE) and energy dispersive X-ray fluorescence (EDXRF). ${ }^{14-25}$

The synchrotron radiation X-ray fluorescence (SR-XRF) is a highly sensitive technique using the synchrotron radiation for the excitation X-ray beam. The advantage of the technique is that an extremely high flux of X-rays can be obtained and that the X-rays are $100 \%$ polarized in the plane of the electron beam. This polarization allows the removal of most of the background usually found under the characteristic X-ray peaks. Thus, the sensitivity of $\mathrm{SR}-\mathrm{XRF}$ is greatly improved compared to conventional XRF techniques. ${ }^{26,27}$ Detection limits achieved by SR-XRF are in the range of $\mathrm{ng} \mathrm{m}^{-3}$. Another advantage is that SR-XRF allows direct sample analysis or is requiring very little pre-treatment of the samples. Furthermore, it is a non-destructive technique providing the possibility for a further analysis. ${ }^{28}$ Thus, due to low concentration of some analytes in PM, SR-XRF can be a powerful tool for the determination of the elemental composition of PM. Until now, the SR-XRF technique has not been extensively used for analysis of PM as there are limited numbers of synchrotron facilities in the world, though the technique has been proven to be very useful in the characterization of the elemental composition of PM..$^{27,29-31}$

The Environmental State Company of São Paulo (CETESB) established standard values for air quality in a sampling time of $24 \mathrm{~h}$ as 120 and $60 \mu \mathrm{g} \mathrm{m}^{-3}$ for $\mathrm{PM}_{10}$ and $\mathrm{PM}_{2.5}$, respectively. Furthermore, the standard value for the annual arithmetic mean value of $\mathrm{PM}_{10}$ and $\mathrm{PM}_{2.5}$ is 40 and $20 \mu \mathrm{g} \mathrm{m}^{-3}$, respectively. ${ }^{32}$ Due to intense mining activities with the extraction, transportation and processing of clay to ceramic material as well as the burning of sugar cane (mainly in dry season), the region of Rio Claro and Santa Gertrudes is considered as the region with the worst air quality indexes in the state of São Paulo. ${ }^{33,34}$ Especially the monitored annual arithmetic mean values of $\mathrm{PM}_{10}$ in Santa Gertrudes and Rio Claro exceeded the standard values with 80 and $46 \mu \mathrm{g} \mathrm{m}^{-3}$, respectively in 2016 . Thus, leading to eminent respiratory problems of the population, especially during dry season. ${ }^{33-35}$
A few studies were realized monitoring air pollution by SR-TXRF in the region of Rio Claro and Santa Gertrudes. SR-TXRF followed by principal component analysis (PCA) and cluster analysis were furthermore used in the study of Canteras et al. ${ }^{31}$ to identify main sources of PM in Limeira (SP), a city about $25 \mathrm{~km}$ away from Rio Claro.

The objective of the present work was the elemental determination of PM suspended in the atmosphere in Rio Claro (SP), using the synchrotron radiation X-ray fluorescence (SR-XRF) of the Brazilian Synchrotron Light Laboratory (LNLS), associating PM composition with possible emission sources present in the region.

\section{Experimental}

\section{Study area}

The city of Rio Claro (SP), located in the central part of São Paulo state (Figure 1), is placed in the Corumbataí River basin, which is part of the Paulista Peripheral Depression. The geological framework is mostly constituted by sediments of the Corumbataí Formation (Neo-Permiano) (Figure 1). ${ }^{36}$ Climate in the region, according to the Köppen-Geiger classification, ${ }^{37,38}$ is defined as subtropical humid (Cwa) characterized by a distinct rainy season (from October to March) and dry season (from April to September). In dry season, mean temperatures are around $17^{\circ} \mathrm{C}$, while in rainy season mean temperatures are around $22{ }^{\circ} \mathrm{C}$. The annual precipitation accounts $1534 \mathrm{~mm}$, in which $77 \%$ being concentrated in the rainier months from October to March. ${ }^{36,37}$

The city of Rio Claro is encompassed by the largest ceramic pole in America, which also includes the municipalities of Santa Gertrudes, Cordeirópolis, Ipeúna, Iracemápolis, Limeira and Piracicaba. This pole accounted for $60 \%$ of the ca. 1 billion square meters of ceramic floors which were produced in Brazil in 2014..$^{39}$ The occurrence of clays in the Corumbataí Formation (Neo-Permian) represents the main supply of the raw material for the region's ceramic pole industries. ${ }^{40}$

Sampling of $\mathrm{PM}_{2.5}$ and $\mathrm{PM}_{10}$ and collection of meteorological data were performed at the meteorological station of Rio Claro at the Center for Environmental Analysis and Planning (CEAPLA)-UNESP, Campus Rio Claro-SP, installed at $22^{\circ} 23^{\prime} 32.1^{\prime \prime S}$ and $47^{\circ} 32^{\prime} 45.3^{\prime \prime} \mathrm{W}$, at an altitude of 625 meters above sea level (MASL). Samples were collected in both rainy and dry season. For rainy season, the collection was carried out in the months December of 2014, January, February and March of 2015 and for dry season in August and September of 2015. This sampling strategy had as objective to verify how 

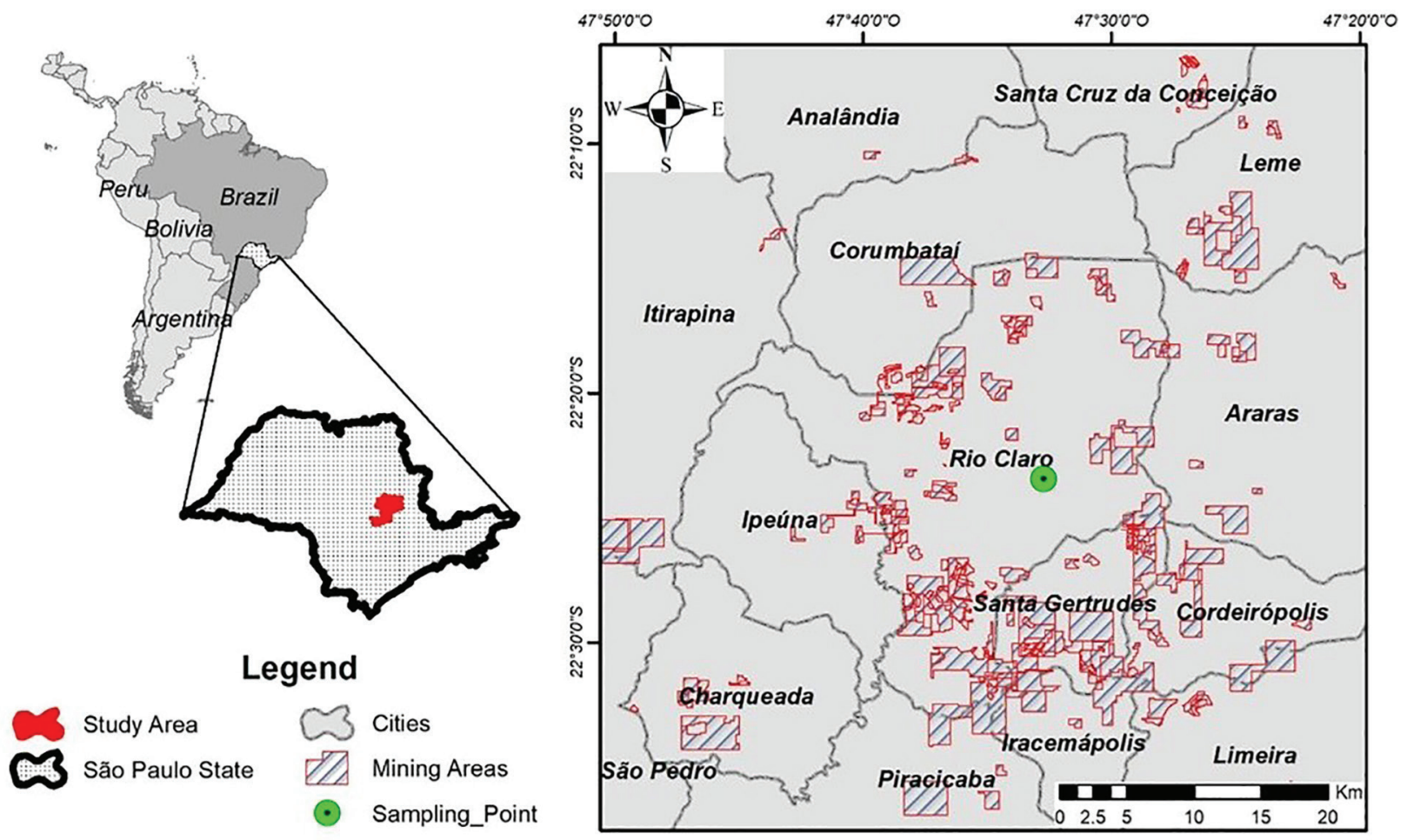

Figure 1. Map showing the location of the municipality of Rio Claro and the site where samples of PM were collected (on left). The spatial distribution of the areas in which mining and industrial activities related to ceramics occur are marked as striped areas on the right map.

different seasonal conditions interfere on the composition of PM.

\section{Sampling program}

The sampling of the particulate matter was realized in a height of $2 \mathrm{~m}$ above the ground using a low-volume "open face" stacked filter unit sampler based on the "Gent" stacked filter unit sampler. ${ }^{41}$ The sampler consisted of an inlet pipe connected to a vacuum pump (constant air flow of about $25 \mathrm{~L} \mathrm{~min}^{-1}$ ) and to a volume totalizer, which allowed to estimate the total concentrations of PM as a function of the volume of air. The sampler has the capacity to collect PM with a diameter lower than $10 \mu \mathrm{m}$ throughout sequential filtration of atmospheric air by inertial impaction in two separately fractions $\left(\mathrm{PM}_{10}\right.$ and $\left.\mathrm{PM}_{2.5}\right)$. $\mathrm{PM}_{10}$ were collected on clean polycarbonate filters $(8 \mu \mathrm{m}$ pore size, $47 \mathrm{~mm}$ total diameter, code TETP04700 by Merck Millipore Ltd., Burlington, USA and code WH10400912 by Whatman Int. Ltd., Kent, UK). $\mathrm{PM}_{2.5}$ were collected on clean polycarbonate filters $(0.4 \mu \mathrm{m}$ pore size, $47 \mathrm{~mm}$ total diameter, code HTTP04700 by Merck Millipore Ltd., Burlington, USA), according to Castanho and Artaxo. ${ }^{21}$ Sampling lag time was $24 \mathrm{~h}$. Each filter was transported inside two clean plastic Petri dishes embedded inside a zip lock plastic bag. After sampling, filters were stored inside the Petri dishes in a desiccator prior to analysis.
During the sampling period between December 2014 and March 2015, 32 samples were collected, while in the period between August and September 2015, 20 samples were collected.

\section{Analytical methods}

The $\mathrm{PM}_{10}$ and $\mathrm{PM}_{2.5}$ filters were directly analyzed by synchrotron radiation X-ray fluorescence (SR-XRF) at the D09-XRF beamline of the Brazilian Synchrotron Light Laboratory (LNLS), Campinas, Brazil. The filters were irradiated by a polychromatic X-ray beam (5 to $20 \mathrm{keV}$ ) with a height of $0.45 \mathrm{~mm}$ and a width of $2 \mathrm{~mm} .{ }^{42}$ The detection of characteristic X-rays was carried out using a $4 \mu \mathrm{m}$ polymer window Ultra-LGe semiconductor detector with $30 \mathrm{~mm}^{2}$ active area and $140 \mathrm{eV}$ resolution at $5.9 \mathrm{keV}$. The filters were analyzed in triplicate at three different positions, where every position was analyzed once. The calculated relative standard deviation of these three measurements were in average lower than $10 \%$ in all samples. The acquisition time was $150 \mathrm{~s}$ for each reading.

The X-ray sample spectra were deconvoluted by the WinAxil X-Ray Analysis software. ${ }^{43}$ All the X-ray characteristic intensities were normalized using the X-ray excitation beam scattered by a Kapton foil. The sensitivities of $\mathrm{Si}, \mathrm{S}, \mathrm{K}, \mathrm{Ca}, \mathrm{Ti}, \mathrm{Cr}, \mathrm{Mn}, \mathrm{Fe}, \mathrm{Cu}$ and $\mathrm{Zn}$ were calculated by the Standard Reference Material ${ }^{\circledR}$ 2782-air 
particulate on filter media (National Institute of Standards and Technology-NIST, Gaithersburg, USA). Finally, the elemental concentration was determined according equation 1.

$\mathrm{C}=(\mathrm{I} \times \mathrm{A}) /(\mathrm{S} \times \mathrm{V})$

where $\mathrm{C}$ is the elemental concentration $\left(\mathrm{ng} \mathrm{m}^{-3}\right)$, I the $\mathrm{X}$-ray characteristic intensity (cps), A the filter area $\left(\mathrm{cm}^{2}\right), \mathrm{S}$ the sensitivity $\left(\mathrm{cps} \mathrm{ng}^{-1} \mathrm{~cm}^{2}\right)$ and $\mathrm{V}$ the volume of air passed through the filter during each sampling $\left(\mathrm{m}^{3}\right)$.

The limit of quantification (LOQ) was estimated using equation 2.

$\mathrm{LOQ}=(10 \times \mathrm{A} \times \sqrt{ }(\mathrm{BG} / \mathrm{t})) /(\mathrm{S} \times \mathrm{V})$

where LOQ is the limit of quantification $\left(\mathrm{ng} \mathrm{cm}^{-3}\right), \mathrm{BG}$ the background intensity under the analyte peak (cps) and the acquisition time (s). ${ }^{44}$

\section{Statistical analysis}

The geochemical association between the elements present in the particulate matter can help in the elucidation of its origin and primary source. Thus, an exploratory statistical analysis that enables the determination of the correlation coefficients between the elements can allow the evaluation of the origin of PM. ${ }^{29}$ In this sense, high positive correlation values may indicate the same source of emission of the elements. Thus, the Pearson correlation matrices for the elements determined in the samples were calculated.

A non-parametric Kruskal-Wallis test was performed in order to investigate if elemental concentrations in PM from dry season and rainy season are statistically different to each other.

The affinity between the elements was also evaluated through cluster analysis, which is a common and important tool in atmospheric pollution studies, as it allows the identification of groups of elements that have similar properties. ${ }^{45-47}$ This technique aims to analyze the geometric proximity between the studied objects verifying the measured average Euclidean distance between them, which can be visualized through dendrograms. In these analyses, the chemical elements that have smaller distances are grouped together suggesting similar characteristics. ${ }^{47}$

PCA was carried out in order to identify factors which indicate the degree of contribution of distinct emission sources of PM. PCA is a widely used tool in air pollution studies for realizing source apportionment of PM..$^{29,31,48}$

All statistical tests in this work were performed by BioEstat 5.3. ${ }^{49}$

\section{Calculation of enrichment factors}

A method, which makes it possible to determine the extent of the contribution of anthropogenic emissions, is the quantification of the enrichment factor (EF) from the definition of a reference element, which presents a defined single source..$^{50}$ Generally, these reference elements are selected among those elements that present higher concentrations in both the origin (soil, rock) and in PM, besides being associated to natural emissions. ${ }^{51}$ In this evaluation, enrichment factor values (for each metal) less than 10 generally indicate that this metal is not significantly enriched from another source, therefore being of natural origin..$^{52}$

The calculation of the enrichment factor is made from the following equation:

$\mathrm{EF}_{\mathrm{EL}}=\frac{[\mathrm{EL}]_{\mathrm{PM}}}{[\mathrm{REF}]_{\mathrm{PM}}} / \frac{[\mathrm{EL}]_{\text {rock }}}{[\mathrm{REF}]_{\text {rock }}}$

where, $\mathrm{EF}$ is the enrichment factor, EL is the concentration of the element of interest and REF is the concentration of the conservative element.

$\mathrm{Si}$ and Fe were selected as conservative elements for this analysis, since both are present in the mineralogical framework of the geological units present in the study area. $\mathrm{Si}$ is being more abundant in $\mathrm{PM}_{10}$ and $\mathrm{Fe}$ in $\mathrm{PM}_{2.5}$.

As a reference for the determination of enrichment factors, the average chemical composition of the main lithotypes present in the Corumbataí Formation was taken, which is the geological unit on which the city of Rio Claro is located on. The main oxidants and their concentrations in this unit are: $\mathrm{SiO}_{2}(62.7 \%) ; \mathrm{TiO}_{2}(1.45 \%) ; \mathrm{Fe}_{2} \mathrm{O}_{3}(5.66 \%)$; $\mathrm{MnO}$ (0.14\%); $\mathrm{CaO}$ (6.42\%); $\mathrm{K}_{2} \mathrm{O}$ (2.08\%); $\mathrm{Cr}$ (24.9 ppm); $\mathrm{Cu}$ (17.3 ppm); Zn (13.6 ppm). ${ }^{53}$

\section{Results and Discussion}

\section{Meteorological data}

A clear climatic distinction between the sampling periods was stated (Table S1, Supplementary Information (SI) section). In the sampling campaign during rainy season, the daily mean temperatures varied between 21.0 and $26.9{ }^{\circ} \mathrm{C}$ with a mean temperature of $24.1^{\circ} \mathrm{C}$ and a total precipitation of $110.6 \mathrm{~mm}$ distributed along the 23 sampling days. In this period, the winds were mainly present from east to east-southeast, southeast and south-southeast to south, south-southwest and southwest (Figure 2). During the second sampling campaign in dry season, the daily mean temperatures varied between 18.0 and $22.5^{\circ} \mathrm{C}$ with 
a mean temperature of $19.6^{\circ} \mathrm{C}$ and a total precipitation of $30.2 \mathrm{~mm}$ distributed along 20 sampling days. Here, winds were mainly present from east-northeast, east, south and southwest.

Using the data of wind direction and wind speed established by the meteorological station of Rio Claro, wind roses for the sampling dates in rainy and dry season were generated with the WRPLOT View Freeware. ${ }^{54}$ Also, for all sampling dates, air mass back trajectories were calculated using the HYSPLIT model (Hybrid Single-Particle Lagrangian Integrated Trajectory, version 4.7). ${ }^{55}$ The trajectories in both sampling periods are partly congruent to the measured wind directions for these days as they mainly come from the north, north-east and east direction, where less mining and ceramic activities are located (Figure 3 ).

\section{Elemental composition of PM}

In order to determine concentrations of the elements of interest deposited in the filters by EDXRF, the sensitivity values for each element were determined using the certified sample of NIST SRM 2783 No. 965 (Table 1).
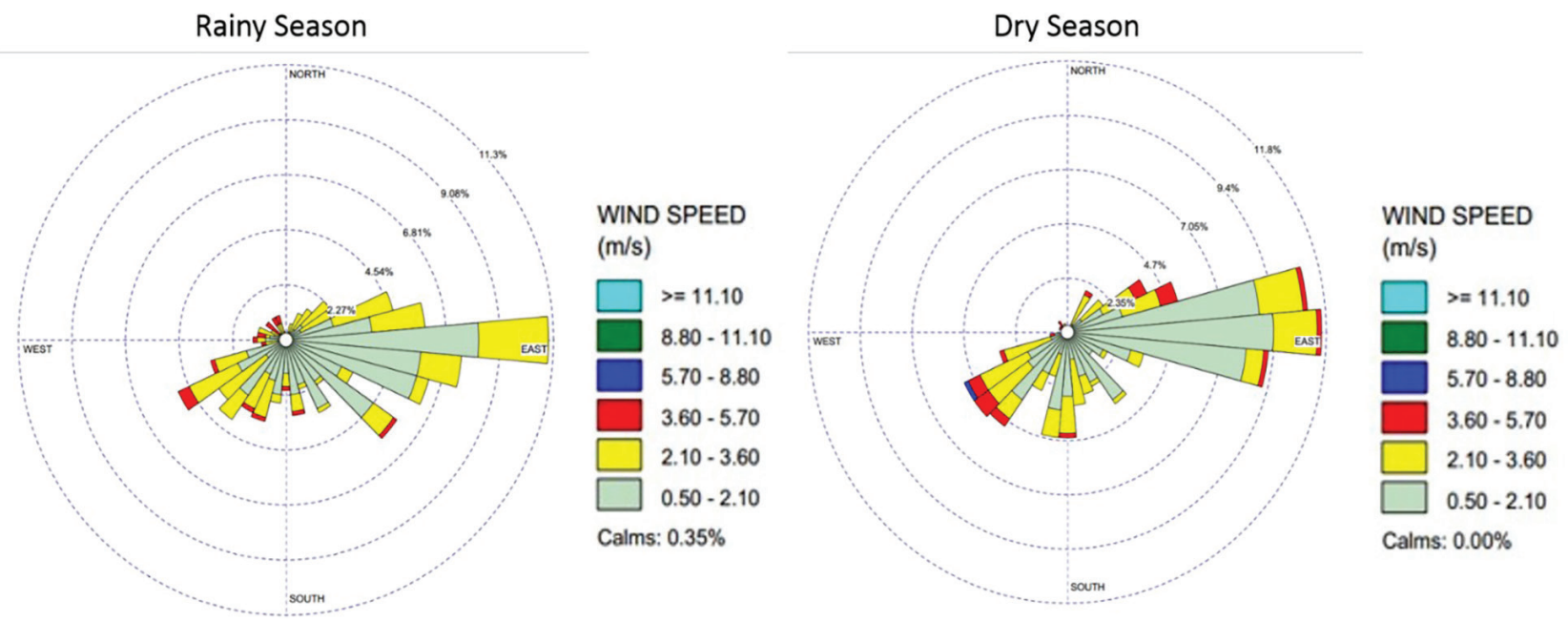

Figure 2. Wind directions for sampling days in rainy and dry season.

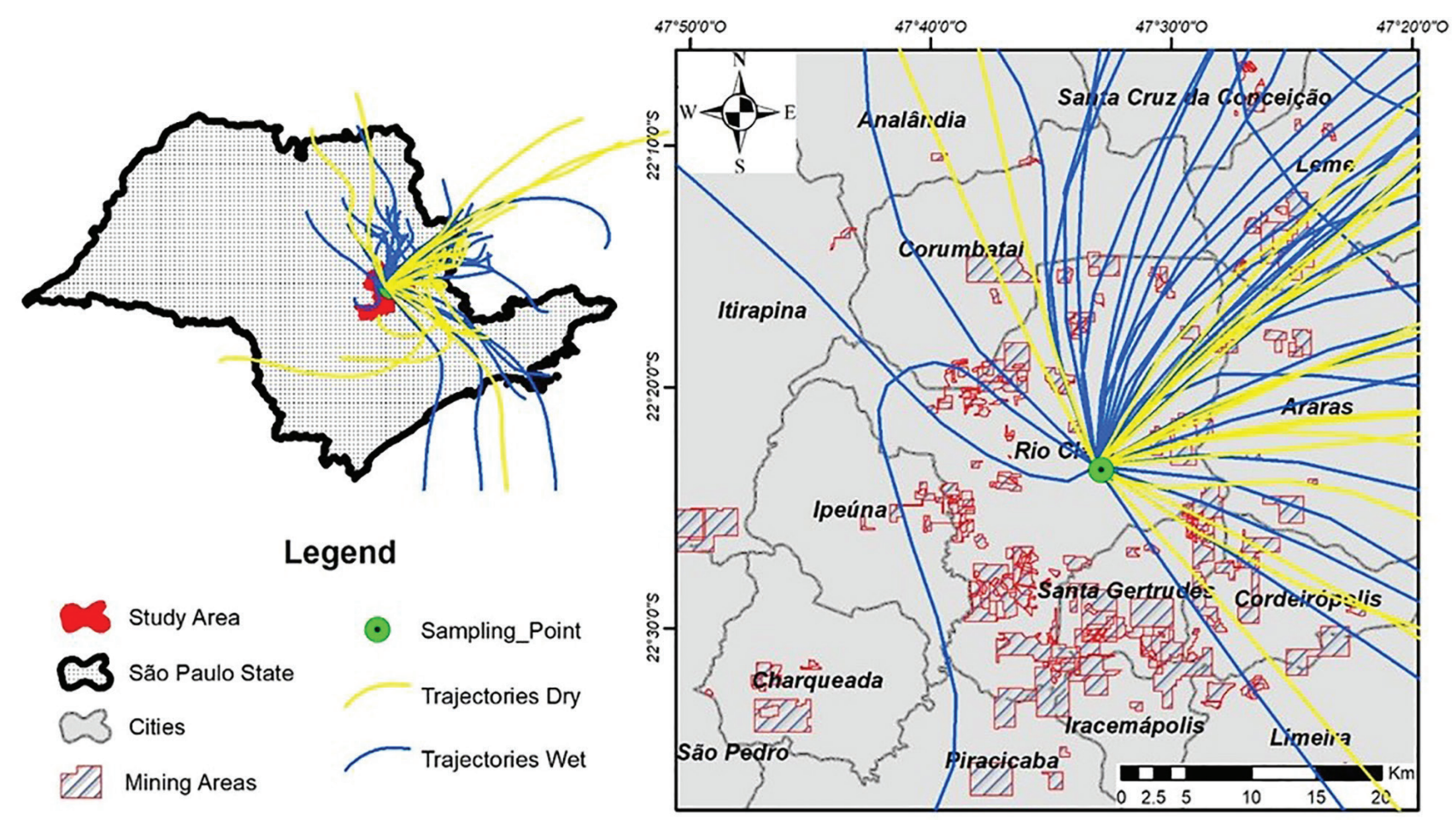

Figure 3. Back trajectory plots ending at 0 AGL of sampling days in rainy (blue) and dry (yellow) season arriving at sampling point in Rio Claro. 
Table 1. Sensitivity values for all elements detected

\begin{tabular}{lc}
\hline Element & Sensitivity / $\left(\mathrm{cps} \mathrm{ng}^{-1} \mathrm{~cm}^{2}\right)$ \\
\hline $\mathrm{Si}$ & 0.000630 \\
$\mathrm{~S}$ & 0.00451 \\
$\mathrm{~K}$ & 0.0652 \\
$\mathrm{Ca}$ & 0.0945 \\
$\mathrm{Ti}$ & 0.195 \\
$\mathrm{Cr}$ & 0.336 \\
$\mathrm{Mn}$ & 0.379 \\
$\mathrm{Fe}$ & 0.356 \\
$\mathrm{Cu}$ & 0.272 \\
$\mathrm{Zn}$ & 0.237 \\
\hline
\end{tabular}

The analytical results of the mean values of the elemental concentrations are shown in Table 2. The standard deviation (SD) in Table 2 represents the instrumental error, the differences among the analyte content in the filters of each season and the heterogeneity of the particle distribution in the filter. The heterogeneity of the particle distribution on each filter is expressed by the relative standard deviation of the results from the measurement of the three different positions of the filter. The arithmetic mean of this relative standard deviation for the elements $\mathrm{Si}, \mathrm{S}, \mathrm{K}, \mathrm{Ca}, \mathrm{Ti}, \mathrm{Cr}, \mathrm{Mn}, \mathrm{Fe}, \mathrm{Cu}$ and $\mathrm{Zn}$ were 17.02 ; $18.01 ; 12.89 ; 24.32 ; 24.34 ; 29.36 ; 19.06 ; 20.34 ; 27.05$ and $16.77 \%$, respectively. The instrumental error was lower than $2 \%$. Comparing the elemental concentrations in PM obtained in the present study with results obtained from similar studies realized in cities of the same region (Campinas, Londrina, Limeira) ${ }^{29,31,56}$ and of other South American regions (Santiago, Chile; Buenos Aires, Argentina; Córdoba, Argentina), ${ }^{27,48,57}$ nearly all elemental concentrations in $\mathrm{PM}_{10}$ and $\mathrm{PM}_{2.5}$ of the present work show significantly lower values than the concentrations obtained in the mentioned studies. The PM sampling for these studies were all realized downtown in cities with a much higher population and thus higher volume of traffic than the city of Rio Claro. This fact could explain the discrepancy of the elemental concentration in PM from Rio Claro compared with these cities.

Table 2. Mean elemental concentrations (mean) and standard deviations (SD) for $\mathrm{PM}_{10}$ and $\mathrm{PM}_{2.5}$ in the city of Rio Claro

\begin{tabular}{|c|c|c|c|c|c|c|c|c|c|c|}
\hline & \multicolumn{5}{|c|}{$\mathrm{PM}_{10} /\left(\mathrm{ng} \mathrm{m}^{-3}\right)$} & \multicolumn{5}{|c|}{$\mathrm{PM}_{2.5} /\left(\mathrm{ng} \mathrm{m}^{-3}\right)$} \\
\hline & $\mathrm{n}$ & Mean & SD & Max & Min & $\mathrm{n}$ & Mean & $\mathrm{SD}$ & $\operatorname{Max}$ & Min \\
\hline & \multicolumn{10}{|c|}{ Rainy season } \\
\hline $\mathrm{Si}$ & 10 & 941.8 & 292.4 & 1473.6 & 593.3 & 1 & - & - & 363.0 & 363.0 \\
\hline S & 1 & - & - & 94.7 & 94.7 & 10 & 146.3 & 67.9 & 290.8 & 74.9 \\
\hline $\mathrm{Ca}$ & 32 & 79.1 & 57.3 & 199.0 & 18.4 & 25 & 15.6 & 12.6 & 59.9 & 2.6 \\
\hline K & 31 & 52.9 & 27.7 & 119.4 & 19.0 & 26 & 18.6 & 9.4 & 44.9 & 6.9 \\
\hline $\mathrm{Ti}$ & 32 & 33.8 & 29.3 & 128.1 & 3.0 & 23 & 9.1 & 6.2 & 23.0 & 1.9 \\
\hline $\mathrm{Cr}$ & 2 & 3.1 & 1.6 & 4.2 & 2.0 & 0 & $<$ LOQ & $<$ LOQ & $<$ LOQ & $<\mathrm{LOQ}$ \\
\hline $\mathrm{Mn}$ & 32 & 4.7 & 2.2 & 9.1 & 1.7 & 12 & 1.8 & 0.5 & 2.6 & 1.1 \\
\hline $\mathrm{Fe}$ & 32 & 240.9 & 222.7 & 947.5 & 20.3 & 29 & 48.2 & 40.8 & 148.2 & 1.9 \\
\hline $\mathrm{Cu}$ & 1 & - & - & 3.6 & 3.6 & 0 & $<$ LOQ & $<\mathrm{LOQ}$ & $<\mathrm{LOQ}$ & $<\mathrm{LOQ}$ \\
\hline \multirow[t]{2}{*}{$\mathrm{Zn}$} & 7 & 6.3 & 1.7 & 8.4 & 3.5 & 2 & 3.0 & 0.7 & 3.5 & 2.5 \\
\hline & \multicolumn{10}{|c|}{ Dry season } \\
\hline $\mathrm{Si}$ & 17 & 1883.7 & 819.1 & 3449.7 & 819.1 & 0 & $<\mathrm{LOQ}$ & $<\mathrm{LOQ}$ & $<$ LOQ & $<\mathrm{LOQ}$ \\
\hline S & 0 & $<\mathrm{LOQ}$ & $<$ LOQ & $<\mathrm{LOQ}$ & $<\mathrm{LOQ}$ & 3 & 132.4 & 31.3 & 166.5 & 104.8 \\
\hline $\mathrm{Ca}$ & 20 & 272.6 & 128.4 & 658.1 & 10.4 & 16 & 23.3 & 19.2 & 83.7 & 7.5 \\
\hline K & 20 & 150.0 & 59.1 & 315.4 & 26.5 & 16 & 28.6 & 20.3 & 79.2 & 7.0 \\
\hline $\mathrm{Ti}$ & 19 & 103.5 & 43.3 & 189.5 & 15.4 & 17 & 8.7 & 8.7 & 18.9 & 1.1 \\
\hline $\mathrm{Cr}$ & 2 & 2.5 & 0.11 & 2.6 & 2.4 & 2 & 2.0 & 0.3 & 2.2 & 1.8 \\
\hline $\mathrm{Mn}$ & 19 & 10.9 & 4.1 & 19.9 & 3.4 & 8 & 2.4 & 1.02 & 4.2 & 0.9 \\
\hline $\mathrm{Fe}$ & 20 & 763.1 & 362.8 & 1380.9 & 25.6 & 19 & 62.2 & 42.5 & 153.9 & 4.8 \\
\hline $\mathrm{Cu}$ & 2 & 7.9 & 0.3 & 8.1 & 7.7 & 0 & $<\mathrm{LOQ}$ & $<\mathrm{LOQ}$ & $<\mathrm{LOQ}$ & $<\mathrm{LOQ}$ \\
\hline $\mathrm{Zn}$ & 6 & 11.1 & 4.5 & 16.5 & 5.3 & 2 & 4.8 & 0.3 & 5.1 & 4.6 \\
\hline
\end{tabular}

$\mathrm{n}$ : number of samples in which the element was determined; Max: maximum concentration; Min: minimum concentration. Values lower than the quantification limit (<LOQ) were not included. 
In general, it was observed that the average elemental concentrations in $\mathrm{PM}_{10}$ in Rio Claro are higher than those determined in $\mathrm{PM}_{2.5}$. This obtained pattern is congruent to the studies of Matsumoto et al. ${ }^{29}$ and Lopes et al..$^{56}$ Though in the study of Canteras et al., ${ }^{31}$ higher elemental concentrations of $\mathrm{Ca}, \mathrm{Cr}, \mathrm{Mn}$ and $\mathrm{Fe}$ were observed in $\mathrm{PM}_{2.5}$ compared to $\mathrm{PM}_{10}$.

The element $\mathrm{S}$ showed values lower than LOQ in the $\mathrm{PM}_{10}$ samples from Rio Claro in nearly all sampling days. In contrast to this, $\mathrm{S}$ is the element with the highest concentrations in $\mathrm{PM}_{2.5}$ in both rainy and dry season with 146.3 and $132.4 \mathrm{ng} \mathrm{m}^{-3}$, respectively. Though, it is known that sulfates are likely more present in smaller size fractions. ${ }^{58,59}$

In rainy season, major constituents in the $\mathrm{PM}_{10}$ fraction are $\mathrm{Si}, \mathrm{Fe}, \mathrm{Ca}$ and $\mathrm{K}$ with emphasis on the concentrations of $\mathrm{Si}$, the element with the highest content (Table 2). The minor elements as $\mathrm{Cu}$ and $\mathrm{S}$ show sporadic occurrence in $\mathrm{PM}_{10}$, being determined in only one sample, respectively. In $\mathrm{PM}_{2.5}$ samples, concentrations of $\mathrm{S}$ and $\mathrm{Fe}$ were determined, while $\mathrm{Si}$ and $\mathrm{Cu}$ levels were below LOQ. The elemental compositions of $\mathrm{PM}_{10}$ and $\mathrm{PM}_{2.5}$ in rainy season can be characterized by the following order of abundance: $\mathrm{Si}>\mathrm{Fe}>\mathrm{Ca}>\mathrm{K}>\mathrm{Ti}>\mathrm{Zn}>\mathrm{Mn}>\mathrm{Cr}$ in $\mathrm{PM}_{10}$, and for $\mathrm{PM}_{2.5} \mathrm{~S}>\mathrm{Fe}>\mathrm{K}>\mathrm{Ca}>\mathrm{Ti}>\mathrm{Zn}>\mathrm{Mn}$.

For samples collected in dry season (August/September 2015), elemental mean concentrations in $\mathrm{PM}_{10}$ were up to three times larger than in $\mathrm{PM}_{2.5}$ (Table 2). Furthermore, $\mathrm{S}$ were not quantified in any $\mathrm{PM}_{10}$ samples, while $\mathrm{Si}$ and $\mathrm{Cu}$ were not quantified in $\mathrm{PM}_{2.5}$ samples. In dry season, the elements $\mathrm{Si}, \mathrm{Fe}, \mathrm{Ca}, \mathrm{K}$ and $\mathrm{Ti}$ showed the highest concentrations in the $\mathrm{PM}_{10}$ samples, while $\mathrm{S}$ and $\mathrm{Fe}$ showed the highest concentrations in the $\mathrm{PM}_{2.5}$ samples. The elements determined in dry season samples have the following decreasing order of concentration for $\mathrm{PM}_{10}$ and $\mathrm{PM}_{2.5}$, respectively: $\mathrm{Si}>\mathrm{Fe}>\mathrm{Ca}>\mathrm{K}>\mathrm{Ti}>\mathrm{Mn}>\mathrm{Zn}>$ $\mathrm{Cu}>\mathrm{Cr}$ and $\mathrm{S}>\mathrm{Fe}>\mathrm{K}>\mathrm{Ca}>\mathrm{Ti}>\mathrm{Zn}>\mathrm{Mn}>\mathrm{Cr}$. The effect of seasonality on the mean elemental concentrations in $\mathrm{PM}_{10}$ and $\mathrm{PM}_{2.5}$ is clearly shown in the up to 5 times higher concentrations in the samples collected in dry season as the removal of PM is more effective in rainy season. In $\mathrm{PM}_{2.5}$, this seasonal difference in elemental concentrations also occurs, but here it is less expressive. In both sample periods, $\mathrm{Si}, \mathrm{Fe}, \mathrm{Ca}, \mathrm{K}$ and $\mathrm{Ti}$ were the elements with the highest concentrations in $\mathrm{PM}_{10}$ and the elements $\mathrm{S}$ and $\mathrm{Fe}$ were the ones with the highest concentrations in $\mathrm{PM}_{2.5}$. The results of $\mathrm{PM}_{10}$ are congruent with the study of Matsumoto et al. ${ }^{29}$ realized in Campinas, where also $\mathrm{Si}, \mathrm{Fe}$, $\mathrm{Ca}$ and $\mathrm{K}$ in dry season were the elements with the highest concentrations in $\mathrm{PM}_{10}$.

Results of the Kruskal-Wallis test showed that elemental concentrations of $\mathrm{PM}_{10}$ from dry and rainy season in Rio Claro are statistically different to each other as $p$ values under 0.05 for nearly all investigated elements (Si: $p<0.0001$; Ca: $p<0.001$ K: $p<0.0001$; Ti: $p<0.0001$; Mn: $p<0.0001$; Fe: $p<0.0001)$ were established, except for $\mathrm{Zn}(p=0.1)$. These results show a dominant effect of seasonality on the elemental content of $\mathrm{PM}_{10}$ related with the higher amount of precipitation in rainy season. Rainfall can directly remove PM by the manner of wet deposition and through scavenging processes. ${ }^{60,61}$ Thus, lower amounts of $\mathrm{PM}_{10}$ are expected on rainy season showing depleted elemental concentrations. On the other hand, elemental concentrations of $\mathrm{PM}_{2.5}$ from dry and rainy season showed no statistical differences to each other as the performed Kruskal-Wallis test showed, where an $p$ value over 0.05 was determined for all investigated elements (S: $p=0.305$; Ca: $p=0.1491 ; \mathrm{K}: p=0.1776$; Ti: $p=0.3109$; Mn: $p=0.2144 ; \mathrm{Fe}: p=0.2021$ ). Thus, no effect of seasonality regarding the elemental content of $\mathrm{PM}_{2.5}$ is indicated.

The elements that presented the highest correlation among themselves for $\mathrm{PM}_{10}$ collected in rainy season are the following: Fe and Ti $(\mathrm{n}=20 ; \mathrm{r}=0.983, \alpha=<0.0001)$, Fe and Mn ( $\mathrm{n}=19 ; \mathrm{r}=0.801 ; \alpha=<0.0001), \mathrm{K}$ and Mn $(\mathrm{n}=19 ; \mathrm{r}=0.792 ; \alpha=<0.0001), \mathrm{Ca}$ and $\mathrm{K}(\mathrm{n}=20 ; \mathrm{r}=0.855$; $\alpha=<0.0001)$, Ca and $\mathrm{Mn}(\mathrm{n}=19 ; \mathrm{r}=0.825 ; \alpha=<0.0001)$, Ti and Mn ( $\mathrm{n}=19 ; \mathrm{r}=0.765 ; \alpha=0.0001)$ (Table S2, SI section). During this period, Zn presented negligible correlation values with the other quantified elements.

For the $\mathrm{PM}_{10}$ samples that were collected in dry season, the elements that presented the highest correlation are: $\mathrm{Fe}$ and $\mathrm{Ti}(\mathrm{n}=19 ; \mathrm{r}=0.975 ; \alpha=<0.0001), \mathrm{Ca}$ and $\mathrm{K}(\mathrm{n}=19$; $\mathrm{r}=0.83 ; \alpha=<0.0001)$, Mn and $\mathrm{Si}(\mathrm{n}=17 ; \mathrm{r}=0.802$; $\alpha=<0.0001)$, Mn and $\mathrm{Ca}(\mathrm{n}=19 ; \mathrm{r}=0.881 ; \alpha=<0.0001)$, Mn and Ti ( $\mathrm{n}=19 ; \mathrm{r}=0.884 ; \alpha=<0.0001)$, Ca and Fe ( $\mathrm{n}=19 ; \mathrm{r}=0.778 ; \alpha=<0.0001)$, Ca and $\mathrm{Si}(\mathrm{n}=17$; $\mathrm{r}=0.709 ; \alpha=0.0014), \mathrm{Mn}$ and $\mathrm{K}(\mathrm{n}=19 ; \mathrm{r}=0.783$; $\alpha=<0.0001)$ and Ti and $\mathrm{Mn}(\mathrm{n}=19 ; \mathrm{r}=0.884 ; \alpha=0.0002)$ (Table S3, SI section).

In the case of the metals generally associated with the earth's crust, significant correlation coefficients are observed between all the elements that composed the $\mathrm{PM}_{10}$ sampled during dry season. Thus, it is suggested that all these elements have the same origin. During rainy season, low correlation between $\mathrm{Zn}$ and all the other elements were observed, indicating possible contributions of multiple sources for $\mathrm{Zn}$. Also, this low correlation can be associated with soils having a low $\mathrm{Zn}$ content in the study area. In general, the elements present in $\mathrm{PM}_{10}$ correlated in the same way for the two studied periods suggesting for these elements the same source of contribution in the two sampling campaigns. 
For the $\mathrm{PM}_{2.5}$ samples collected during rainy season, it is possible to identify significant correlation only between the elements $\mathrm{Fe}$ and $\mathrm{Ti}(\mathrm{n}=22 ; \mathrm{r}=0.831 ; \alpha=<0.0001)$, $\mathrm{Fe}$ and $\mathrm{K}(\mathrm{n}=22 ; \mathrm{r}=0.784 ; \alpha=<0.0001), \mathrm{Ca}$ and $\mathrm{K}(\mathrm{n}=19 ; \mathrm{r}=0.771 ; \alpha=<0.0001)$, Ti and $\mathrm{K}(\mathrm{n}=22$; $\mathrm{r}=0.751 ; \alpha=<0.0001)$ (Table S4, SI section), suggesting the same origin of these metals, possibly associated to a natural contribution since they are elements present in the rocks that are found in the geological framework of the area.

Among the quantified elements for the $\mathrm{PM}_{2.5}$ samples collected in the dry season, a correlation was observed between $\mathrm{Ca}$ and $\mathrm{K}(\mathrm{n}=15 ; \mathrm{r}=0.781 ; \alpha=0.0006), \mathrm{Ca}$ and $\mathrm{Ti}(\mathrm{n}=15 ; \mathrm{r}=0.768 ; \alpha=0.0008), \mathrm{Ca}$ and $\mathrm{Mn}(\mathrm{n}=8$; $\mathrm{r}=0.895 ; \alpha=0.0027), \mathrm{Ca}$ and $\mathrm{Fe}(\mathrm{n}=15 ; \mathrm{r}=0.818$; $\alpha=0.0002)$, Mn and $K(n=8 ; r=0.93 ; \alpha=0.0008), K$ and $\mathrm{Fe}(\mathrm{n}=15 ; \mathrm{r}=0.74 ; \alpha=0.0016), \mathrm{Mn}$ and $\mathrm{Fe}(\mathrm{n}=8$; $\mathrm{r}=0.923 ; \alpha=0.0011)$ and $\mathrm{Ti}$ and $\mathrm{Fe}(\mathrm{n}=15 ; \mathrm{r}=0.822$; $\alpha=0.0002$ ) (Table S5, SI section). The only element that does not show significant correlation with any of the other elements is $\mathrm{S}$, indicating a distinct origin for this element in relation to the other elements.

The higher correlation between elements in dry season can be associated with seasonal changes in the heights of the planetary boundary layer (PBL). The PBL is the closest layer of the atmosphere to the surface of the earth and plays an important role for the surface-atmosphere exchanges of air pollutants. ${ }^{57}$ The PBL can be related to vertical mixing and thus affecting dilution processes of pollutants, which were emitted near the ground. ${ }^{62,63}$ The mid-day mean heights of the PBL in south-east Brazil can show seasonal difference of up to $1000 \mathrm{~m}$ in average between dry and rainy season. While the mid-day mean heights of the PBL in the months of June, July and August are between 1600 and $1850 \mathrm{~m}$, heights of PBL can show mean values of $2500 \mathrm{~m}$ in the months December, January and February. ${ }^{64}$

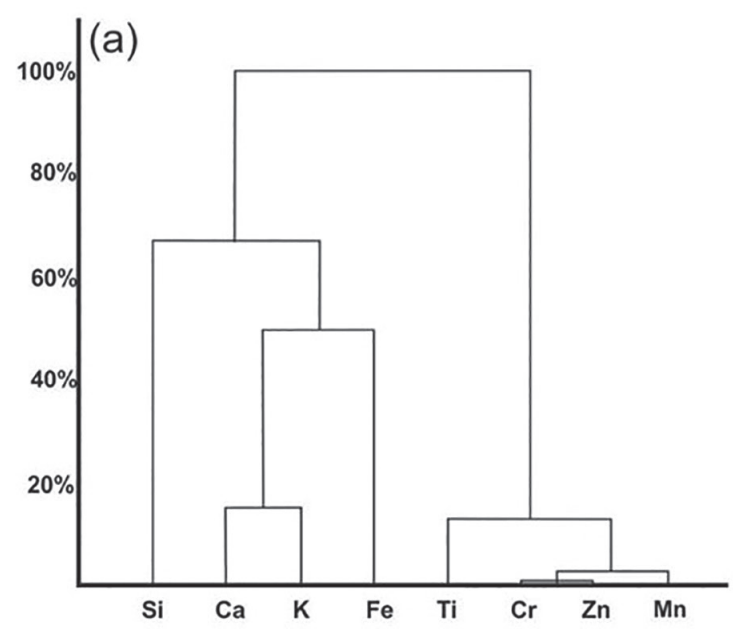

The lower heights of the PBL in dry season mean a lower vertical mixing of air masses and thus, less dilution and lower mixing of pollutants from farther emitting sources occur, resulting in higher correlation values between the elements measured in $\mathrm{PM}_{2.5}$ in dry season. Though, there is no evidence for this assumption as exact data of PBL heights in the region of Rio Claro are scarce.

The evaluation of the dendrogram of $\mathrm{PM}_{10}$ in the two sampling campaigns (Figure 4) shows that the elements $\mathrm{Si}, \mathrm{Ca}, \mathrm{K}$ and $\mathrm{Fe}$ form a segregated group to the group of $\mathrm{Ti}, \mathrm{Cr}, \mathrm{Zn}, \mathrm{Mn}$ and $\mathrm{Cu}$ (especially in dry season). These groups are differentiated by the concentrations of these elements present in PM as the elements of the first group show the highest concentrations and the second group the lower concentrations. The origin of the first group can be directly associated to the dust suspension from the soils existing in the study area. These soils are characterized by the occurrence of clay-minerals rich in $\mathrm{Ca}, \mathrm{K}$ and rich in $\mathrm{Fe}$ oxides and hydroxides (produced by the weathering process of rocks). On the other hand, the second group consisting of the elements Ti, $\mathrm{Cr}, \mathrm{Zn}, \mathrm{Mn}$ and $\mathrm{Cu}$ can be associated with industrial emissions. These results show similarities with the characterization of coarse particulate matter from Limeira by dendrograms in the study of Canteras et al..$^{31}$ Here, also $\mathrm{Ca}, \mathrm{Fe}, \mathrm{K}$ and $\mathrm{S}$, which were associated with soil dust, were segregated as one major group.

PCA analysis for $\mathrm{PM}_{10}$ was applied using 7 variables (elements) for rainy and dry season (Table 3). Results showed that in rainy and dry season one factor is explaining over $75 \%$ of the data variability. The elements $\mathrm{Si}, \mathrm{Ca}, \mathrm{K}$, $\mathrm{Ti}, \mathrm{Mn}$ and $\mathrm{Fe}$ show an even distribution in this factor which can indicate an association with soil dust as emission source. The second factor responsible for 8.09 and $14.22 \%$ in rainy and dry season, respectively, is dominated by $\mathrm{Zn}$. This can be an indicator for industrial emission,

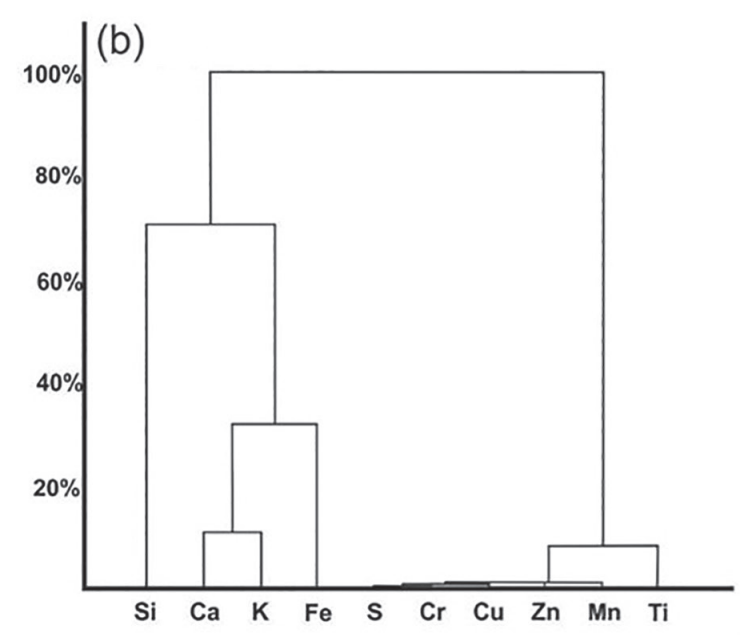

Figure 4. Dendrograms of $\mathrm{PM}_{10}$ samples collected in rainy season (a) and in dry season (b). 
Table 3. Factor loadings of principal components $\left(\mathrm{PC}_{\mathrm{i}}\right)$ for $\mathrm{PM}_{10}$

\begin{tabular}{|c|c|c|c|c|c|c|c|c|}
\hline \multirow{2}{*}{$\mathrm{PM}_{10}$} & \multicolumn{4}{|c|}{ Rainy season } & \multicolumn{4}{|c|}{ Dry season } \\
\hline & PCI & PCII & PCIII & PCIV & PCI & PCII & PCIII & PCIV \\
\hline Eigenvalue & 5.55 & 0.57 & 0.45 & 0.22 & 5.42 & 0.99 & 0.36 & 0.10 \\
\hline Variance / \% & 79.30 & 8.09 & 6.39 & 3.14 & 77.36 & 14.22 & 5.12 & 1.48 \\
\hline Cumul. variance / \% & 79.30 & 87.40 & 93.79 & 96.93 & 77.36 & 91.59 & 96.70 & 98.18 \\
\hline $\mathrm{Si}$ & 0.39 & -0.10 & 0.07 & -0.50 & 0.39 & -0.29 & -0.33 & -0.72 \\
\hline $\mathrm{Ca}$ & 0.39 & -0.34 & 0.22 & 0.47 & 0.41 & 0.18 & -0.07 & -0.17 \\
\hline $\mathrm{K}$ & 0.36 & -0.54 & 0.23 & -0.41 & 0.37 & 0.23 & -0.66 & 0.54 \\
\hline $\mathrm{Ti}$ & 0.39 & 0.37 & -0.42 & -0.17 & 0.40 & -0.26 & 0.43 & 0.29 \\
\hline $\mathrm{Mn}$ & 0.38 & -0.22 & -0.38 & 0.55 & 0.42 & -0.06 & 0.01 & 0.08 \\
\hline $\mathrm{Fe}$ & 0.40 & 0.33 & -0.30 & -0.10 & 0.40 & -0.25 & 0.40 & 0.13 \\
\hline $\mathrm{Zn}$ & 0.33 & 0.54 & 0.70 & 0.19 & 0.22 & 0.83 & 0.33 & -0.23 \\
\hline
\end{tabular}

especially emissions from the ceramic industry, as emission source. These assumptions are supported by the study of Matsumoto et al. ${ }^{29}$ where two factors explaining over $90 \%$ of the data variability of the coarse particulate matter in Campinas were calculated by principal component analysis. Here, factor 1 showed an association between the elements of $\mathrm{Fe}, \mathrm{Si}, \mathrm{Ti}, \mathrm{K}, \mathrm{Al}$ and $\mathrm{Ca}$, representative for soil dust as emitting source. Factor 2 were associated with $\mathrm{Cu}, \mathrm{Ni}, \mathrm{S}$, $\mathrm{Zn}$ and $\mathrm{Cr}$, representative for industrial emission sources. ${ }^{29}$

Due to the non-determination of some of the elements analyzed in the sampling campaigns for $\mathrm{PM}_{2.5}$, the cluster analysis produced different results for the two sampled periods. Despite this lack of information, an affinity between $\mathrm{Ca}, \mathrm{Ti}, \mathrm{K}$ and $\mathrm{Mn}$ in dry season was observed (Figure 5). For the samples of $\mathrm{PM}_{2.5}$ collected during rainy season in Rio Claro, the main elements associated with each other are also of natural origin, but these strongly correlate with S, basically an element of anthropogenic origin. This fact can occur due to the presence of water in the atmosphere, recurrent of this period, that promotes the adsorption of $\mathrm{S}$ in the particles of natural origin present in the atmosphere. ${ }^{4}$

PCA carried out for $\mathrm{PM}_{2.5}$ samples was using 6 variables (elements) (Table 4). Results also showed one dominant factor taking into account 73.53 and $83.82 \%$ of the total variability in rainy and dry season, respectively. In both seasons, contributions of the elements $\mathrm{S}, \mathrm{Ca}$, $\mathrm{K}, \mathrm{Ti}, \mathrm{Mn}$ and $\mathrm{Fe}$ in this factor are nearly even, which are associated with soil dust as emitting source. In the further factors, no clear pattern of significant elements could be established for apportion them to an emitting source. A similar domination of a factor with significant elements being associated with soil dust emissions were also carried out by Matsumoto et al..$^{29}$ ( $\mathrm{Al}, \mathrm{Si}, \mathrm{Ti}, \mathrm{Fe}, \mathrm{Ca}$ and $\mathrm{K}$ ) and Canteras et al. ${ }^{31}$ ( $\mathrm{Ti}, \mathrm{Ba}, \mathrm{K}, \mathrm{Fe}$, and $\mathrm{Ca}$ ) in the PCA of $\mathrm{PM}_{2.5}$.
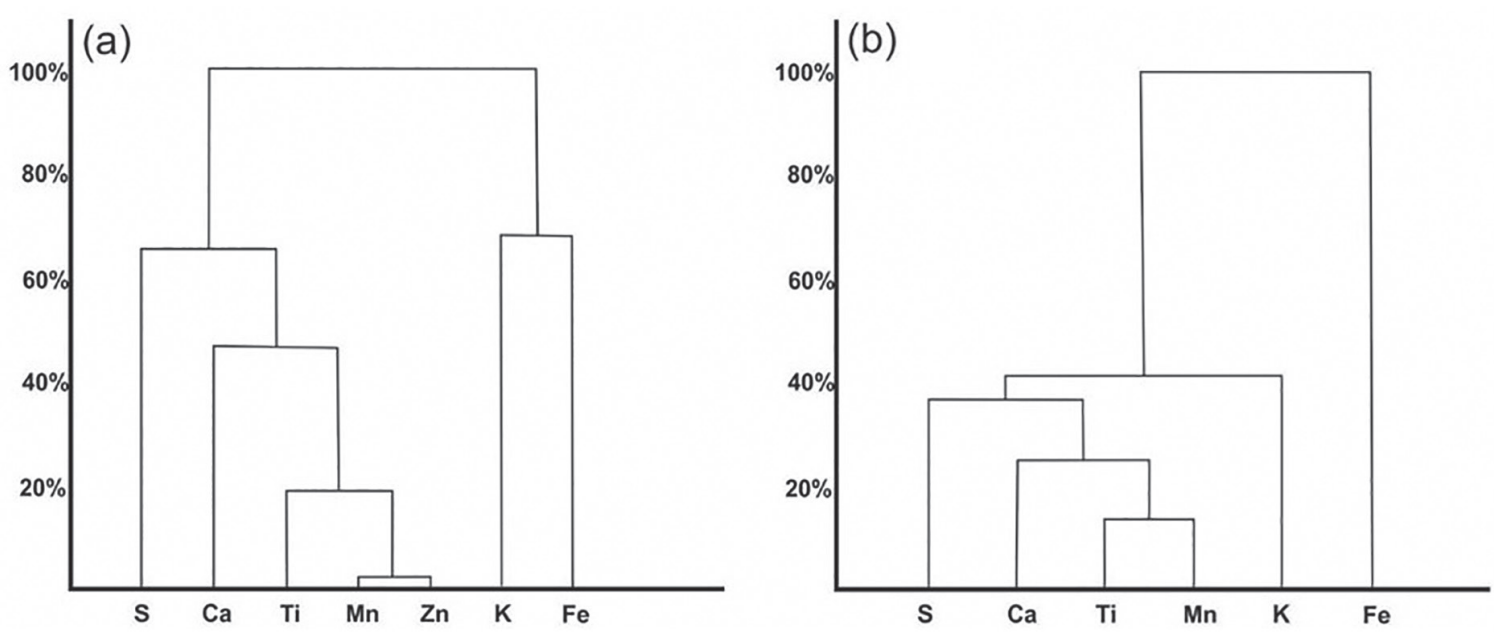

Figure 5. Dendrograms of $\mathrm{PM}_{2.5}$ samples collected in rainy season (a) and in dry season (b). 
Table 4. Factor loadings of Principal components $\left(\mathrm{PC}_{\mathrm{i}}\right)$ for $\mathrm{PM}_{2.5}$

\begin{tabular}{|c|c|c|c|c|c|c|c|c|}
\hline \multirow{2}{*}{$\mathrm{PM}_{2.5}$} & \multicolumn{4}{|c|}{ Rainy season } & \multicolumn{4}{|c|}{ Dry season } \\
\hline & PCI & PCII & PCIII & PCIV & PCI & PCII & PCIII & PCIV \\
\hline Eigenvalue & 4.41 & 0.58 & 0.51 & 0.26 & 5.03 & 0.41 & 0.30 & 0.12 \\
\hline Variance / \% & 73.53 & 9.60 & 8.49 & 4.28 & 83.82 & 6.88 & 5.03 & 1.98 \\
\hline Cumul. Variance / \% & 73.53 & 83.13 & 91.62 & 95.90 & 83.82 & 90.71 & 95.73 & 97.71 \\
\hline$S$ & 0.36 & -0.60 & -0.66 & -0.11 & 0.38 & -0.69 & -0.41 & 0.10 \\
\hline $\mathrm{Ca}$ & 0.41 & -0.10 & 0.57 & -0.50 & 0.43 & -0.18 & -0.18 & -0.53 \\
\hline K & 0.40 & -0.51 & 0.40 & 0.38 & 0.40 & -0.09 & 0.80 & -0.31 \\
\hline $\mathrm{Ti}$ & 0.43 & 0.39 & -0.28 & -0.22 & 0.39 & 0.63 & -0.34 & -0.19 \\
\hline $\mathrm{Mn}$ & 0.42 & 0.34 & -0.02 & 0.70 & 0.42 & 0.01 & 0.20 & 0.74 \\
\hline $\mathrm{Fe}$ & 0.44 & 0.33 & -0.06 & -0.24 & 0.42 & 0.30 & -0.09 & 0.17 \\
\hline
\end{tabular}

The $\mathrm{PM}_{2.5}$ samples from dry season presented $\mathrm{Fe}$ as the most abundant element since this element was quantified in most of the samples, besides presenting the highest values of correlation with the other elements. Due to these high correlations of the elements with $\mathrm{Fe}$, it can be stated that $\mathrm{PM}_{2.5}$ collected during dry season also has a strong influence of natural emission processes.

The analysis of dendrograms and PCA indicated a strong contribution of soil dust to the $\mathrm{PM}_{10}$ and $\mathrm{PM}_{2.5}$ in rainy and dry season in Rio Claro. These results are consistent with similar studies carried out in the same region. Although, these patterns differ with studies carried out downtown in large cities like Santiago de Chile, Córdoba and Buenos Aires where urban dust (mainly $\mathrm{Pb}, \mathrm{Ba}, \mathrm{Cr}, \mathrm{S}, \mathrm{Al}, \mathrm{V}, \mathrm{Si}$, $\mathrm{Co})$, traffic emissions $(\mathrm{Fe}, \mathrm{S}, \mathrm{Ni})$ and road erosion are the main contribution factors for PM..$^{27,48,57}$ Furthermore, results of PCA in Rio Claro is too vague to use this method on its own for source apportionment as a much lesser number of variables (elements) were included in the analysis than in the mentioned studies above.

Calculated enrichment factors are shown in Figure 6. Evaluation of the results indicates that EF calculated for

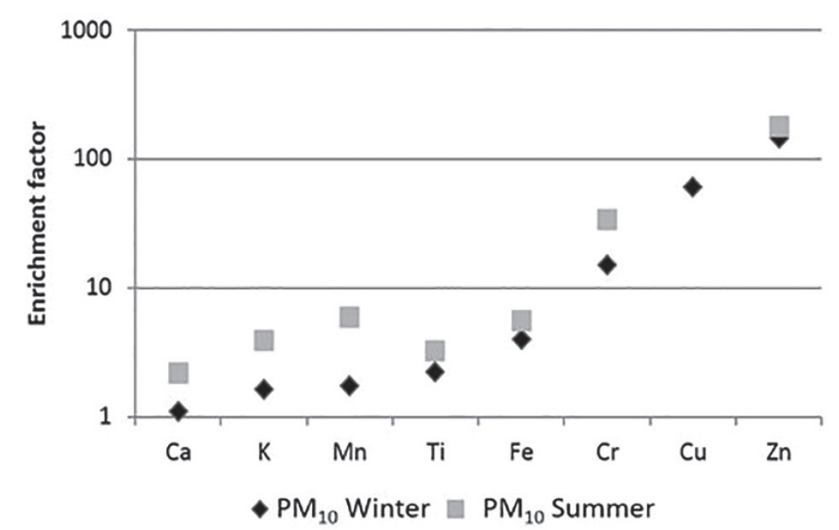

$\mathrm{PM}_{10}$ are larger than those calculated for $\mathrm{PM}_{2.5}$. It also shows a well-marked seasonal variation with higher EF in rainy than in dry season. The elemental evaluation indicates that the elements $\mathrm{Ca}, \mathrm{K}, \mathrm{Mn}, \mathrm{Ti}$ and $\mathrm{Fe}$ have origins associated with sources of natural emissions such as the resuspension of soil dust as they show EF values lower than $10 .^{50}$ On the other hand, the elements $\mathrm{Cu}, \mathrm{Cr}$ and $\mathrm{Zn}$ for the entire sample set presented enrichment values higher than 10 , suggesting concentrations enriched by anthropogenic emission sources. S did not have its EF determined as no reference concentration was found for these rocks. Elevated enrichment factors of $\mathrm{Zn}$ were also obtained in the study of da Silva et al. ${ }^{65}$ where PM from the ceramic production area in the Vale do Açu in North-Eastern Brazil was characterized. Here also Ba showed high enrichment factors which were not determined in the present study.

Elemental monitoring of PM carried out in São Carlos, a city in the interior of state of São Paulo, also indicated that $\mathrm{Fe}, \mathrm{Ca}, \mathrm{K}, \mathrm{Mn}$ and $\mathrm{Ti}$ are associated with sources of natural origin and the elements $\mathrm{Zn}, \mathrm{Cr}$ and $\mathrm{Cu}$ are associated to anthropogenic sources, especially to vehicular emissions. ${ }^{66}$

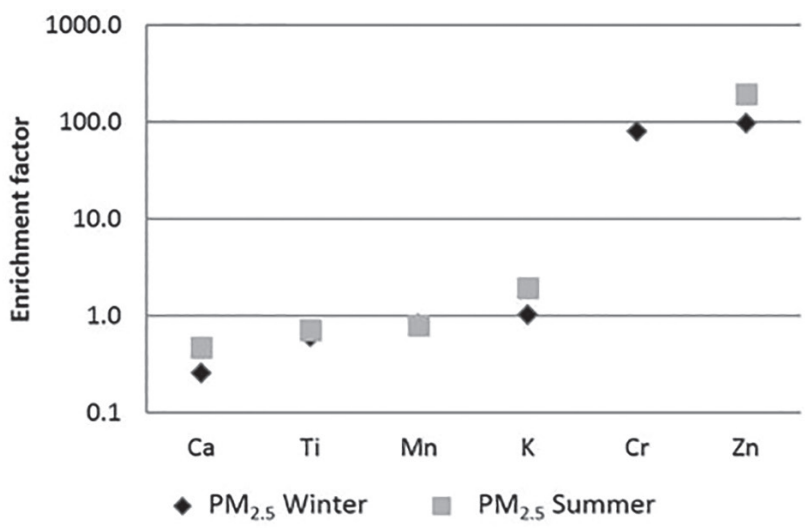

Figure 6. Graphical representation of the average enrichment factor of the quantified elements in the $\mathrm{PM}_{10}$ and $\mathrm{PM}_{2.5}$ samples collected in Rio Claro in dry and rainy season. Scale in $\log 10$. 
Furthermore, in the present study, concentrations of $\mathrm{Cr}$ and $\mathrm{Zn}$ in $\mathrm{PM}_{2.5}$ showed enrichment factor values typical of anthropogenic sources, while the other elements presented enrichment factors typical of natural sources. The same behavior was observed in the study of Lopes et al..$^{56}$ carried out in Londrina. In Rio Claro, the enrichment of $\mathrm{Zn}$ and $\mathrm{Cr}$ in $\mathrm{PM}_{2.5}$ and $\mathrm{PM}_{10}$ can be associated with the emissions caused by the production of ceramics since the use of inorganic pigments in the manufacturing process of the coating of ceramics is based on $\mathrm{Cr}$ and $\mathrm{Zn}$ components.

In both sampling periods, wind directions and back trajectories were mainly coming from east, south-east or north-east direction while the main mining and ceramic activities are in the south, south-west and south-east of the sampling point. This may indicate to a lesser influence of ceramic emissions on the PM in Rio Claro.

\section{Conclusions}

The sampling campaigns carried out in dry and rainy season allowed an approach on the issue of air pollution in Rio Claro-SP. The information obtained in these campaigns allowed the creation of a database on the elemental composition of $\mathrm{PM}_{2.5}$ and $\mathrm{PM}_{10}$. The synchrotron radiation X-ray fluorescence (SR-XRF) technique proved to be suitable for the analysis of samples of PM deposited on thin polycarbonate films, requiring no pre-treatment of the sample prior analysis, being expeditious and presenting low quantification limits.

A distinct effect of seasonality for $\mathrm{PM}_{10}$ was observed as elemental concentrations in dry season are significantly higher than in rainy season. This effect could not be attested for the elemental concentrations of $\mathrm{PM}_{2.5}$. Elemental correlation studies, cluster analysis, PCA and enrichment factor calculation allowed the distinction of the main sources of emission of PM, which were vehicular and industrial emissions (presumably from the adjacent ceramic industry).

Although the studies carried out in this work have allowed an approach regarding atmospheric pollution by the particulates in the city of Rio Claro, subsequent studies are necessary for a better understanding of the magnitude of the polluting sources, depending on the climatic variations in order to promote corrective measures that will guarantee a better quality of life for the population.

\section{Supplementary Information}

Supplementary information (Tables S1-S5) is available free of charge at http://jbcs.sbq.org.br as PDF file.

\section{Acknowledgments}

The authors thank the Center of Analysis and Environmental Planning-CEAPLA Unesp, Campus of Rio Claro for ceding the climatic data and the collection site and the Brazilian Light Synchrotron Laboratory (LNLS), proposal D09-XRF-Project 18917 for providing infrastructure for the analysis of the study samples. Also, the authors thank the foundations Conselho Nacional de Desenvolvimento Científico e Tecnológico (CNPq: MEC/SETEC/CNPq No. 94/2013), Coordenação de Aperfeiçoamento de Pessoal de Nível Superior (CAPES), Fundação de Amparo à Pesquisa do Estado de São Paulo (FAPESP) and Fundação de Apoio a Pesquisa, Ensino e Extensão (Funep) for their financial support.

\section{Author Contributions}

Thiago de A. Dourado was responsible for conceptualization, data curation, formal analysis, investigation, methodology, visualization, writing-original draft; Hendryk Gemeiner for conceptualization, data curation, formal analysis, investigation, methodology, software, validation, writing-original draft, writing-review and editing; Ana Carla Fernandes Gomes for funding acquisition, methodology, project administration, supervision, writingreview and editing; Eduardo Almeida: conceptualization, formal analysis, investigation, methodology, supervision, validation, writing-original draft, writing-review and editing; Adivania Cardoso da Silva for data curation, formal analysis; Nayara Valadão for data curation, formal analysis; Amauri Antônio Menegário for formal analysis, funding acquisition, investigation, methodology, project administration, resources, supervision, writing-original draft, writingreview and editing; José Silvio Govone for data curation, investigation, software, writing-original draft, writing-review and editing; Didier Gastmans for conceptualization, data curation, investigation, project administration, software, supervision, validation, visualization, writing-original draft, writing-review and editing.

\section{References}

1. Pope III, C. A.; Dockery, D. W.; J. Air Waste Manage. Assoc. 2006, 56, 709.

2. Baird, C.; Environmental Chemistry, $5^{\text {th }}$ ed.; W. H. Freeman \& Company: New York, USA, 2012.

3. Finlayson-Pitts, B. J.; Pitts, J. N. P.; Chemistry of the Upper and Lower Atmosphere; Academic Press: San Diego, USA, 2000.

4. Jacobson, M. Z.; Atmospheric Pollution History, Science and Regulation; University Press: Cambridge, UK, 2002. 
5. Brunekreef, B.; Holgate, S. T.; Lancet 2002, 360, 1233.

6. Lewtas, J.; Mutat. Res. 2007, 636, 95.

7. Pope III, C. A.; Burnett, R. T.; Thun, M. J.; Calle, E. E.; Krewski, D.; Ito, K.; Thurston, G. D.; JAMA 2002, 287, 1132.

8. World Health Organization (WHO); Air Quality Guidelines for Particulate Matter, Ozone, Nitrogen Dioxide and Sulphur Dioxide; Global update 2005, Summary of Risk Assessment; WHO: Geneva, Italy, 2006.

9. Godish, T.; Air Quality; CRC Press: Boca Raton, USA, 1997.

10. Wang, H.; Shooter, D.; Sci. Total Environ. 2005, 340, 189.

11. Braga, B.; Introdução à Engenharia Ambiental; Prentice Hall: São Paulo, Brazil, 2002.

12. Monfort, E.; Celades, I.; Mestre, S.; Sanz, V.; Querol, X.; Key Eng. Mater. 2004, 264-268, 2453.

13. Minguillón, M.; Monfort, E.; Querol, X.; Alastuey, A.; Celades, I.; Miró, J.; J. Environ. Manage. 2009, 90, 2558.

14. Ariola, V.; D’Alessandro, A.; Lucarelli, F.; Marcazzan, G.; Mazzei, F.; Nava, S.; Garcia-Orellana, I.; Prati, P.; Valli, G.; Vecchi, R.; Zucchiatti, A.; Chemosphere 2006, 62, 226.

15. Vallius, M.; Janssen, N. A. H.; Heinrich, J.; Hoek, G.; Ruuskanen, J.; Cyrys, J.; Grieken, R. V.; de Hartog, J. J.; Kreyling, W. G.; Pekkanen, J.; Sci. Total Environ. 2005, 337, 147.

16. Sillanpää, M.; Hillamo, R.; Saarikoski, S.; Frey, A.; Pennanen, A.; Makkonen, U.; Spolnik, Z.; Van Grieken, R.; Braniš, M.; Brunekreef, B.; Chalbot, M.; Kuhlbusch, T.; Sunyer, J.; Kerminen, V.; Kulmala, M.; Salonen, R.; Atmos. Environ. 2006, 40, 212.

17. Yele, S.; Guoshun, Z.; Ying, W.; Lihui, H.; Jinghua, G.; Mo, D.; Wenjie, Z.; Zifa, W.; Zhengping, H.; Atmos. Environ. 2004, 38,5991 .

18. Lestiani, D. D.; Santoso, M.; Trompetter, W. J.; Barry, B.; Davy, P. K.; Markwitz, A.; J. Radioanal. Nucl. Chem. 2013, 297, 177.

19. Chiari, M.; Yubero, E.; Calzolai, G.; Lucarelli, F.; Crespo, J.; Galindo, N.; Nicolás, J. F.; Giannoni, M.; Nava, S.; Nucl. Instrum. Methods Phys. Res., Sect. B 2018, 417, 128.

20. Andrade, M. F.; Orsini, C.; Maenhaut, W.; Atmos. Environ. 1994, 28, 2307.

21. Castanho, A.; Artaxo, P.; Atmos. Environ. 2001, 35, 4889.

22. Ynoue, R. Y.; Andrade, M. F.; Aerosol Sci. Technol. 2004, 38, 52.

23. Miranda, R.; Tomaz, E.; Atmos. Res. 2008, 87, 147.

24. Ventura, L. M. B.; Amaral, B. S.; Wanderley, K. B.; Godoy, J. M.; Gioda, A.; J. Braz. Chem. Soc. 2014, 25, 1571.

25. Silva, F. S.; Godoi, R. H. M.; Tauler, R.; de André, P. A.; Saldiva, P. H. N.; van Grieken, R.; de Marchi, M. R. R.; J. Environ. Prot. 2015, 6, 426.

26. Wilson, W. E.; Chow, J. C.; Claiborn, C.; Fusheng, W.; Engelbrecht, J.; Watson, J. G.; Chemosphere 2002, 49, 1009.

27. López, M. L.; Ceppi, S.; Palancar, G. G.; Olcese, L. E.; Tirao, G.; Toselli, B. M.; Atmos. Environ. 2011, 45, 5450.
28. Bukowiecki, N.; Lienemann, P.; Zwicky, C. N.; Furger, M.; Richard, A.; Falkenberg, G.; Rickers, K.; Grolimund, D.; Borca, C.; Hill, M.; Gehrig, R.; Baltensperger, U.; Spectrochim. Acta, Part B 2008, 63, 929.

29. Matsumoto, E.; Simabuco, S. M.; Pérez, C. A.; Nascimento Filho, V. F.; X-Ray Spectrom. 2002, 31, 136.

30. Imre, K.; Molnar, A.; Idojaras 2008, 112, 63.

31. Canteras, F. B.; Moreira, S.; Faria, B. F.; X-Ray Spectrom. 2013, 42, 290.

32. https://cetesb.sp.gov.br/ar/padroes-de-qualidade-do-ar/accessed in December 2019.

33. Companhia Ambiental do Estado de São Paulo (CETESB); Relatório de Qualidade do Ar no Estado de São Paulo 2015; CETESB: São Paulo, 2016. Available at https://cetesb.sp.gov. br/ar/wp-content/uploads/sites/28/2013/12/RQAR-2015.pdf, accessed in December 2019.

34. Companhia Ambiental do Estado de São Paulo (CETESB); Relatório de Qualidade do Ar no Estado de São Paulo 2016; CETESB: São Paulo, 2017. Available at https://cetesb.sp.gov. br/wp-content/uploads/2017/09/relatorio-ar-2016.pdf, accessed in December 2019.

35. Freitas, C. U.; Junger, W.; Leon, A. P.; Grimaldi, R. S.; Mirta, A. F. R.; Gouveia, N.; Epidemiol. Serv. Saúde 2013, 22, 445.

36. Zaine, M. F.; Perinotto, J. A. J.; Patrimônios Naturais e História Geológica da Região de Rio Claro-SP; Câmara Municipal de Rio Claro e Arquivo Público Histórico do Município de Rio Claro: Rio Claro, 1996.

37. Alvares, C. A.; Stape, J. L.; Sentelhas, P. C.; Gonçalves, J. L. M.; Sparovek, G.; Meteorol. Z. 2013, 22, 711.

38. Peel, M. C.; Finlayson, B.; McMahon, T. A.; Hydrol. Earth Syst. Sci. 2007, 4, 439.

39. Azzi, A. A.; Osacký, M.; Uhlík, P.; Čaplovičová, M.; Zanardo, A.; Madejová, J.; Appl. Clay Sci. 2016, 132, 232.

40. Companhia Ambiental do Estado de São Paulo (CETESB); Projeto Corumbataí Cerâmicas Negociação de Conflitos Ambientais com o Envolvimento de Segmentos Sociais e o Polo Cerâmico de Santa Gertrudes; CETESB: Piracicaba, Brazil, 2005. Available at https://www.cetesb.sp.gov.br/ noticentro/2006/01/corumbatai.pdf, accessed in December 2019.

41. Maenhaut, W.; François, F.; Cafmeyer, J.; The "Gent" Stacked Filter Unit Sampler for the Collection of Atmospheric Aerosols in Two Size Fractions: Description and Instructions for Installation and Use; Applied Research on Air Pollution Using Nuclear-related Analytical Techniques, IAEA Report NAHRES-19 249-263, Vienna, Austria, 1994. Available at https://inis.iaea.org/collection/NCLCollectionStore/_ Public/25/054/25054927.pdf?r=1\&r=1, accessed in December 2019.

42. Pérez, C. A.; Radtke, M.; Sánchez, H. J.; Tolentino, H.; Neuenshwander, R. T.; Barg, W.; Rubio, M.; Bueno, M. I. S.; 
Raimundo, I. M.; Rohwedder, J. J. R.; X-Ray Spectrom. 1999, $28,320$.

43. WinAxil X-Ray Analysis Software Model S-5005, Canberra Eurisys Benelux N.V./S.A, Zellik, Belgium, 2015.

44. Nascimento Filho, V. F.; Poblete, V. H.; Parreira, P.; Matsumoto, E.; Simabuco, S. M.; Espinoza, E. P.; Navarro, A. A.; Biol. Trace Elem. Res. 1999, 71, 423.

45. Rajšić, S.; Mijić, Z.; Tasić, M.; Radenković, M.; Joksić, J.; Environ. Chem. Lett. 2008, 6, 95.

46. Richter, P.; Griño, P.; Ahumada, I.; Giordano, A.; Atmos. Environ. 2007, 41, 6729.

47. Yusup, Y.; Alkarkhi, A. F. M.; Chem. Ecol. 2010, 27, 273.

48. Artaxo, P.; Oyola, P.; Martinez, R.; Nucl. Instrum. Methods Phys. Res., Sect. B 1999, 150, 409.

49. BioEstat, versão 5.3; Instituto Mamirauá, Tefé, AM, Brazil, 2019.

50. McLennan, S. M.; Geochem., Geophys., Geosyst. 2001, 2, 1021.

51. Na, K.; Cocker III, D. R.; Atmos. Res. 2009, 93, 793.

52. Ure, A. M.; Davidson, C. M.; Chemical Speciation in the Environment; Blackie Academic \& Professional: London, UK, 1995.

53. Conceição, F. T.; Bonotto, D. M.; Rev. Bras. Geof. 2006, 24, 37.

54. WRPLOT View-Air Dispersion Modelling, versão 8.0.2; Lakes Environmental Software, Waterloo, ON, Canada, 2018.

55. Stein, A. F.; Draxler, R. R.; Rolph, G. D.; Stunder, B. J. B.; Cohen, M. D.; Ngan, F.; Bull. Am. Meteorol. Soc. 2015, 96, 2059 .
56. Lopes, F.; Appoloni, C. R.; Nascimento, V. F.; Melquiades, F. L.; Almeida, L. C.; J. Radioanal. Nucl. Chem. 2006, $270,43$.

57. Reich, S.; Robledo, F.; Gomez, D.; Smichowski, P.; Environ. Monit. Assess. 2009, 155, 191.

58. Kerminen, V.-M.; Hillamo, R.; Teinilä, K.; Pakkanen, T.; Allegrini, I.; Sparapani, R.; Atmos. Environ. 2004, 35, 5255.

59. Groma, V.; Osán, J.; Török, S.; Meirer, F.; Streli, C.; Wobrauschek, P.; Falkenberg, G.; Idojaras 2008, 112, 83.

60. Luan, T.; Guo, X. L.; Zhang, T. H.; Guo, L. J.; J. Meteorol. Res. 2019, 33, 126.

61. Bing Gao, B.; Ouyang, W.; Cheng, H.; Xu, Y.; Lin, C.; Chen, J.; Atmos. Environ. 2019, 218, 117000.

62. Emeis, S.; Schäfer, K.; Bound.-Layer Meteorol. 2006, 121, 377.

63. Su, T.; Li, Z.; Kahn, R.; Atmos. Chem. Phys. 2018, 18, 15921.

64. McGrath-Spangler, E. L.; Denning, A. S.; J. Geophys. Res.: Atmos. 2013, 118, 1226.

65. da Silva, K. K.; Duarte, F. T.; Matias, J. N. R.; Dias, S. A. M. M.; Duarte, E. S. F.; Soares, C. G. C. S.; Hoelzemann, J. J.; Galvão, M. F. O.; Atmos. Pollut. Res. 2019, 10, 597.

66. Celli, C. E.; Marques, K. A.; Teixeira, D.; Bachiega, E.; Machado, A. P.; Carvalho, W. V.; Aguiar, M. L.; Coury, J. R.; Eng. Sanit. Ambiental 2003, 8, 6.

Submitted: September 26, 2019

Published online: January 16, 2020 